\title{
European Silver Paper on the future of health promotion and preventive actions, basic research and clinical aspects of age-related diseases
}

Silver Paper — dokument końcowy europejskiego szczytu dotyczącego przyszłości promocji zdrowia, działań prewencyjnych, badań podstawowych i klinicznych aspektów chorób wieku podeszłego

\begin{abstract}
Alfonso J. Cruz-Jentoft ${ }^{1}$, Alain Franco ${ }^{2}$, Pascal Sommer ${ }^{3}$, Jean-Pierre Baeyens ${ }^{4}$ Ewa Jankowska ${ }^{5}$, Adriana Maggi ${ }^{6}$, Piotr Ponikowski ${ }^{7}$ Andrzej Rys ${ }^{8}$, Katarzyna Szczerbińska ${ }^{9}$, Andrzej Milewicz ${ }^{10}$ and all other participants of EUROPEAN SUMMIT- AGE-RELATED DISEASES ${ }^{11}$
\end{abstract}

${ }^{1}$ University Hospital Ramon y Cajal, Madrid, Spain

${ }^{2}$ University Joseph Fourier, Grenoble, France

${ }^{3}$ Institute of Biology and Chemistry of Proteins, University Lyon, France

${ }^{4}$ General Damian Hospital, Ostende, Belgium

${ }^{5}$ Institute of Anthropology, Polish Academy of Sciences, Wroclaw, Poland

${ }^{6}$ Center of Excellence on Neurodegenerative Diseases University of Milan, Italy

${ }^{7}$ Military Hospital, Wroctaw, Poland

${ }^{8}$ Public Health and Risk Assessment DG SANCO EC, Bruxelles, Belgium

${ }^{9}$ Institute of Public Health, Jagiellonian University Medical College, Cracow, Poland

${ }^{10}$ Department of Endocrinology, Diabetology and Isotope Therapy, Medical University, Wrocltaw

${ }^{11}$ See list at the end of the paper

\begin{abstract}
The current article is a statement of the meeting with international and multidisciplinary participation, held in Wrocław, Poland on September 11-13, 2008. The meeting was devoted to working out a position focusing on the challenge for individuals, health care systems, biological, psychosocial, epidemiological, medical, and public health sciences in the ageing populations of the twenty-first century. The statement is presented as an overview, in tabular format, of the current European situation regarding basic biological research on ageing, health promotion and preventive action, clinical care for older people, and recommendations for future actions.
\end{abstract}

(Pol J Endocrinol 2009; 60 (5): 408-414)

Key words: ageing, age-related diseases, geriatry

\section{Streszczenie}

W niniejszym artykule przedstawiono ustalenia, jakie zapadły podczas Europejskiego Szczytu poświęconego chorobom związanym ze starzeniem - European Summit - Age Related Diseases, który odbył się we Wrocławiu w dniach 11-13 września. Celem tego międzynarodowego spotkania, w którym uczestniczyli specjaliści z różnych dziedzin medycyny było uzgodnienie wspólnego stanowiska na temat indywidualnych potrzeb chorych, systemów opieki medycznej, badań biologicznych, psycho-społecznych, epidemiologicznych i dotyczących zdrowia publicznego w aspekcie starzenia się populacji w XXI wieku. Stanowisko to przedstawiono w końcowym dokumencie zawierającym charakterystykę obecnej sytuacji w Europie odnośnie do badań podstawowych nad biologią procesów starzenia, promocji zdrowia i działań prewencyjnych, opieki klinicznej nad osobami w podeszłym wieku, a także zalecenia na przyszłość.

(Endokrynol Pol 2009; 60 (5): 408-414)

Słowa kluczowe: starzenie się, choroby związane z wiekiem, geriatria 


\section{Introduction}

The increase of life expectancy of the world population is one of the highest achievements of humankind, and Europe is leading this successful story. However, ageing and age-related disease are also mounting challenges for individuals, for health care systems, and for biological, psychosocial, epidemiological, medical, and public health sciences. Many scientists from every single area of knowledge and science are actively working to better understand ageing and to tackle the challenges that it brings to twenty-first century individuals.

These challenges cannot be confronted from a single point of view. A coordinated, active, united front of many disciplines is needed to face them, and a strategy that, starting from basic research, reaches every single aspect of ageing is needed. This means that translational research is a fundamental requirement, and that advances coming from research should flow rapidly through the education of professionals to the promotion of healthy lifestyles, and to health and social care meeting the needs of older people. Evidence-based lifespan strategies for successful ageing must be adopted, with appropriate adaptation for older people to cater for the heterogeneity and complexity of later life.

A better understanding of molecular mechanisms of ageing, embedded in a translational matrix of gerontology ${ }^{1}$ and geriatric medicine, is an absolute requirement for the design of new clinical procedures for improved prevention and management of age-associated dysfunctions and diseases. Moreover, placing greater stress and increasing research on public health issues (including health promotion and protection, prevention of disease, disability and frailty, improving quality of life, quality of care, health care organisation, and health economy aspects) will result in better application of results from basic and clinical research into everyday practice (i.e. from efficacy to effectiveness). Connecting public health research with research in other sciences may result in translating knowledge to health policy and strategic plans concerning older persons and their family caregivers.

Major advances in basic ageing research have been made possible by recent breakthroughs showing that the mechanisms underlying ageing are conserved in evolu- tion, so that the biology of ageing can now be studied by looking at the causal mechanisms at work in ageing, integrating approaches from senescent cells in vitro to model systems and human studies. We now have the tools and resources, in the form of tractable experimental systems ranging from the sub-cellular, through animal models (such as nematodes, insects or rodents) to humans, in order to investigate the molecular mechanisms that cause ageing. The identification of the basic mechanisms determining ageing will enable the generation of novel prognostic markers and therapeutic means to promote healthy ageing and prevent age-associated disease.

Clinical and public health research has also offered new insights about prevention and care in age relateddisease. Much is known about the prevention and treatment of many acute and chronic diseases that result in disability and impaired quality of life. However, many European citizens are not receiving up-to-date care and rehabilitation of these diseases, and are suffering an avoidable burden of suffering and disability. Older people are not obtaining benefits from many advances in clinical gerontology and in disease prevention. Public health policies addressing the specific needs of older persons, and changes in the way that medical advances are delivered to this population are needed, in order to obtain more efficient, financially sustainable systems of health and social care. Moreover, research is needed to better define the role of many relevant social and economical aspects of ageing and disease.

In our modern society, older people are frequently subject to ageism, suffering discrimination relating to the scale and scope of services they receive in comparison to younger people. Even the terminology used towards older people is often inappropriate, and we concur with the proposal of the Human Rights Commission of the United Nations in 1999 to adapt our vocabulary, by not using the word "elder$1 y^{\prime \prime}$, and using instead the term "older people", a more respectful approach. This change has to be adapted to every language.

The following is a brief overview, in tabular format, of the current European situation in basic biological research on ageing, in health promotion and preventive action, and in clinical care for older people, and the recommendations for future actions.

${ }^{1}$ Gerontology, the science of ageing, is classically divided into four sub-disciplines: i) social sciences of ageing, ii) psychology of ageing, iii) biology of ageing, and iv) clinical gerontology (within which are positioned the disciplines of geriatric medicine, old age psychiatry, and gerontological nursing, among others). It deals with the globality of normal ageing in the first instance. 


\begin{tabular}{ll}
\hline We know & Basic research \\
\hline $\begin{array}{l}\text { A fundamental but poorly understood aspect of ageing is the } \\
\text { asynchronous deterioration of organs and tissues within an } \\
\text { individual. How the intrinsic rate of ageing within the different } \\
\text { tissues is determined, how the whole body copes with this }\end{array}$ & $\begin{array}{l}\text { A multidisciplinary and integrated approach is recommended, } \\
\text { in organisms ranging from simple models to humans, } \\
\text { aiming to address the question of how ageing is modulated at } \\
\text { system level. The fact that the rate of ageing differs } \\
\text { individuals, remains elusive. }\end{array}$ \\
$\begin{array}{l}\text { considerably between tissues is of high clinical relevance. } \\
\text { Understanding the basic molecular mechanisms responsible } \\
\text { for asynchronous ageing and the natural mechanisms that might } \\
\text { counteract these deteriorations will provide the basis for novel } \\
\text { diagnostic, preventive, and therapeutic strategies. This } \\
\text { programme could be supported through an INTEGRATIVE } \\
\text { PROJECT: "Call text - LSH: Asynchrony in tissue ageing". }\end{array}$ \\
\hline
\end{tabular}

Intrinsic as well as external (nutrition and environment) factors regulate the progression and conditions of ageing and age-related disease by modulating gene expression at the epigenetic and posttranscriptional level. In the post-genomic era, it is becoming increasingly clear that epigenetic factors are critical determinants of ageing in diverse organisms ranging from yeast to humans. Epigenetic modulation of ageing has not been systematically addressed so far.
Epigenetic contributions to ageing and age-related dysfunctions and diseases should be studied in a comprehensive way. This should be done in an integrated, multidisciplinary approach, using experimental systems ranging from simple animal models to humans, in order to address the question of how ageing is modulated by epigenetic mechanisms.

Experimental models should be developed in a way allowing the translation of basic research into health care at different levels, including preventative care, diagnosis, and therapeutics. This knowledge would add significantly to the competitiveness of European ageing research. This programme could be supported through an INTEGRATIVE PROJECT: "Call text - LSH: Epigenetic modulation of ageing processes".

Health promotion and preventive action

We know We recommend

The altered demography of the world requires the incorporation of the principles of gerontology and geriatric medicine into those of public health.

Compliance (adherence) is a major factor limiting the effectiveness of health promotion and preventive interventions. Older people may not respond well to interventions when they do not match with their beliefs, attitudes, preferences, expectations, and aspirations.

Strategies of successful ageing consist of having the opportunity to make and making healthy lifestyle choices, implementing various self-management techniques, being offered and taking advantage of immunisation, injury prevention, early detection interventions and correct treatment of disease. Maintaining social network and activities is also critical to adapt successfully to aging health challenges.

Appropriate nutrition and nutritional care are key indicators for quality of life, disease prevention and sustainable health. Nutritional care is not just a cost item but part of the health care solution.
Training of public health professionals and academics should routinely incorporate clinical gerontology as a core component of undergraduate and postgraduate curricula.

Public health strategies to promote health and quality of life should be based on a life course approach. They should also take into account older people's views as well as new information from longitudinal studies on ageing, rather than being paternalistic.

Selection of the appropriate evidence based screening tests for older people is of great importance in order to reduce disability, morbidity and mortality, and avoid unnecessary, expensive and potentially harmful diagnostic and treatment procedures.

Adaptations of vaccine recommendations for older adults, and different subgroups such as those living in the community and the institutionalized oldest old are needed. The main aim should be to promote preventive aspects in primary and secondary care, as well as in geriatric medicine, relating to both life threateningdiseases, and diseases that adversely impact the patient's independence and quality of life. Efforts should be made to guarantee a lifelong approach to adequate vaccinations to improve immunological response to infectious diseases.

Older persons should be encouraged to maintain good nutritional habits. They should be screened for nutritional status and should be proposed adequate nutritional interventions. All health and allied care professionals should be trained in nutritional care. European countries should consider developing national nutritional care plans. 
Physical activity is one of the most important factors alleviating 'successful ageing'. Maintaining independence, reducing morbidity, and increasing quality of life are important beneficial effects of physical activity in older people.

Falls are more common in older people with poor balance; Falls are not an inevitable consequence of ageing: there is good evidence that progressive balance and strength interventions reduce risk of falls amongst older people.

Injuries are an important cause of morbidity, disability, and mortality among older people, impacting the quality of life and representing an increasingly large proportion of the health expenditure. Despite the fact that almost half of the injuries are now foreseeable and preventable, efforts to reduce the injury toll in this age group have so far been limited, inconsistent, and dispersed across different settings. the age-related decline of biological potential and enabling decreased strength and mobility are important risk factors.

On a population/public health basis, encouraging physical activity and the provision of a range of exercise opportunities as part of a wider campaign on prevention of falls and maintenance of independence should be popularised. Exercise recommendations should also be implemented as a secondary preventive measure in the recommendations of disease management. The use of published evidence-based recommendations for engagement of older people in preventive health care and the training of a wide range of health, social care, and leisure professionals in order to meet the full range of needs, abilities, and preferences of older people is important.

Strengthening capacity building in the training of professionals working with older people; networking of researchers, practitioners and policy makers across Europe; and implementation of preventive programmes can significantly contribute to the reduction and prevention of both intentional (like suicide, abuse, violence) and unintentional (like falls, traffic accidents, poisoning, and burns) injuries among community-dwelling and institutionalised older persons. These targets can be achieved through coordinated actions at European, national, or local level by providing state-of-the-art information on evidence-based practices for injury prevention that have proven to be effective.

Mental stimulation using cognitively challenging activities is a means to facilitate neural plasticity, which can increase cognitive reserve and result in maintained or improved cognitive functioning.

On a population/public health basis, the use of memory training, mental stimulation, and mental compensation strategies, and the training of a wide range of health professionals in order to promote cognitive stimulation activities in older people should be encouraged.

Social activity and social inclusion of older people is a complex and still under-appreciated issue with regard to successful ageing. Social activities include professional work, recreation, voluntary activity, family life, as well as a sense of duty towards disabled older persons or small children.

Facilitating and enhancing social activity in older people is important for society, not only in the sphere of the labour market, but also in other social (voluntary) initiatives, and as a preventive measure against social exclusion. The enormous reserve of human capital offered by older people's activity should be recognised by policy makers and adequately supported. To improve the quality of retirement in future generations, the teaching of initiatives that promote social activity and engagement should start at school, from a life course perspective.

Informal care giving has an important role in health promotion, prevention, and care of frail, disabled, older individuals. In the future, demographic aging in most European countries may also result in a substantial reduction of the number of informal caregivers available to care for disabled older persons.
Measures to improve public and governmental appreciation of the immense unpaid work performed by informal caregivers should be developed (i.e. a European Caregivers' Day). Support, training, and incentives (including financial incentives) should be offered to informal caregivers, based on the needs expressed by themselves through their organisations, and the insights offered by social and clinical gerontology.

Clinical care

\section{We know}

Geriatric medicine is the specialty concerned with health related problems in older people, including acute, chronic, and rehabilitation problems, in the community, long-stay, and hospital settings. It is of proven efficacy in health promotion, health gain, health maintenance, and palliative care for older people. Geriatric medicine is an independent medical specialty in the majority of European countries, but not in all, although the number of older patients and the complexity of their medical conditions are growing fast. Old age psychiatry is also largely underdeveloped in most European countries, while some mental health diseases have a growing prevalence and impact on the quality of life of older individuals. Specialist gerontological nursing is an enormously important means of ensuring better care of older people within the healthcare system.

\section{We recommend}

European countries should encourage the universal recognition and further development of geriatric medicine as a medical specialty. An appropriate number of specialist physicians in geriatric medicine should be trained, certified, and incorporated into national health systems. Old age psychiatry should also be developed.

There is clear need for specialist training across all heath and social care professions (including nursing, social work, physiotherapy, occupational therapy, clinical psychology, and public health practitioners) to meet the challenges of successful ageing. 
The use of drugs in older people is complex. Age related changes in pharmacokinetics and pharmacodynamics, polypharmacy, multiple comorbid diseases, and drug-drug, as well as drug-disease interactions all increase the number and severity of adverse drug reactions (ADR). Moreover, non-adherence to treatment may limit the success of any therapy. Many hospital admissions are due to ADR in this population. Discrimination against older people by their exclusion from clinical drug trials limits the body of evidence on which therapeutic decisions can be correctly made. In many cases, evidence-based, life-saving therapies are not offered to older individuals.

\section{Multifactorial interventions led by geriatricians}

(i.e. hospital acute geriatric assessment units, models of integrated care, old age psychiatry, rehabilitation, home care) have been shown to result in better patient outcomes (such as lower disability and mortality, reduced need for long term care, etc) at a similar or lower cost than usual care.
A Geriatric Medicine Committee should be established within the European Medicines Agency (EMEA) to improve research on every aspect of drug use in older people, to improve the appropriateness of drug treatments in complex situations, and to reduce patient risk.
Services for health care for older persons are heterogeneous, and the availability of acute care, rehabilitation, long-term care, palliative care, old age psychiatry, home care, and nursing homes differs greatly not only between European countries, but even within most of them. Often, these services do not incorporate the fundamentals of modern clinical gerontology. This is a breach of the UN Convention of Human Rights, which mandates the right to the highest achievable standard of health care. The right of an older European citizen to receive comprehensive, up-to-date geriatric medical and social care currently depends greatly on his/her place of residence.

Care for specific groups of older patients is also extremely heterogeneous between and within European countries.

Multidimensional comprehensive geriatric assessment should be made available to every older person, and fitted to each individual's profile. A comprehensive management plan should be elaborated, implemented, and periodically reviewed. The objective is not only to restore health, but also to restore and maintain the highest possible level of independence and physical and mental autonomy. Interventions that have been clearly shown to improve health outcomes should be offered to affected older people. Outcomes should be adapted to the needs of each individual, who may prefer autonomy to longevity.

In the very near future, older patients admitted to hospitals in the European Union should have access to specialist geriatric care, which will offer coordinated and integrated multidisciplinary care, adapted to the needs of each individual, their families, and caregivers. In case of illness, frail and complex older people in Europe should have access to treatment provided by geriatricians and their teams. Technological aids have to be gradually incorporated in all aspects of care of older people. Each European country should develop a full spectrum of high quality services for older people, which includes health care (both in- and out-patient, acute, and chronic), home care, and care homes, and make them financially sustainable, available, and accessible to all those in need.

Palliative and end-of-life care, informed by evidence and the principles of clinical gerontology and geriatric medicine should be made available for older individuals who have diseases in their late and final stages, at the moment they need it. Palliative medicine should not be targeted to cancer patients only. Old age psychiatry should also be developed to address adequately in the future the large share of mental health problems that affect older persons (dementia, delirium, etc).

Long-term care for older people is an under-funded and Many individuals do not get a comprehensive assessment to determine their therapeutic and rehabilitation potential, frequently resulting in a failure to recognise the complexity of health and social care needs. A huge amount of care rests on family periods of time. under-resourced area of practice in most European countries. members who bear the costs and responsibility, usually for long

Older people should receive a comprehensive assessment to determine the need for long-term care and the possibility of recovering enough function to live in a less complex environment. This needs assessment that should lead to appropriate investigation, treatment and support, using a bio-psycho-socio-spiritual model informed by modern clinical gerontology and geriatric medicine principles. Long-term care professionals should be trained in the effective use of validated comprehensive assessment tools and individual care plans for residents. A quality of care assurance system should be implemented in long-term care facilities to protect older people against discrimination, marginalisation, and malpractice. Informal caregivers should be supported emotionally, socially, financially, and with technological innovations, and should have access to support services.

\footnotetext{
A big share of health care of older patients depends on general practitioners /family physicians, and on monospecialists. However, most of these physicians receive very little, if any, teaching on the multiple aspects of care of older people.
}

Medical schools should have academic departments of geriatric medicine to provide leadership in undergraduate and postgraduate training and research. Every student of medical, nursing, or allied health professions (physio-occupational and other therapies, social work, etc) should receive teaching and should be trained in old age medicine and psychiatry, and this should become a mandatory part of the academic curriculum and post-graduate training of all health care professionals. 
Health services research rarely includes frail older individuals. Research outcomes that are relevant for younger populations (i.e. mortality) may lose importance at advanced age. Health service research is limited, and the impact of changes in the organization and delivery of health services regarding the function and health of older people is rarely considered.
Research in the prevention and treatment of disabling and chronic disorders should: a) include the full spectrum of people who are likely to benefit from it (including frail, older people, taking into account gender differences in ageing), b) use relevant outcomes, which include not only mortality, but also disability, use of health care and community services, quality of care, and quality of life, c) be informed by evidence and the principles of modern clinical gerontology and geriatric medicine, and d) include public health issues. There is also an obvious and continuing need for research in the way that health services have to adapt to meet the new challenges brought about by changes in demography, diseases, demands, disability, and social support.

Research in old age health and disease is fragmented, with limited interactions between basic, epidemiological, preventive, clinical, and health service research. Translational research is particularly sparse, despite evidence of the difficulties to translate demonstration projects into routine health care delivery. Ineffective treatment strategies are wasteful of ever-scarcer resources.
A European Institute of Ageing would be an excellent answer, able to improve basic, translational, and applied research in the ageing process, and in the prevention, treatment, and rehabilitation of diseases of older people. It would bring awareness, funds, leadership, and coordination. In view of our, as yet, limited understanding of the benefits and challenges of an ageing Europe. It would also contribute to the vision of the Lisbon declaration that Europe would have the most competitive knowledge-based economy in the world by 2010 .

\section{List of Participants of the European Summit on Age-Related Disease (Wroclaw, 11-13 September 2008):}

\section{The European Silver Paper was based on reports by:} Karen Andersen-Ranberg, University of Southern, Denmark; Francesco Benvenuti University of Empoli, Italy; Barbara Bień Medical University Białystok, Poland; Piotr Błędowski, International Institute of Molecular and Cell Biology, Warsaw, Poland; Julia Buján, University of Alcala, Madrid, Spain; Christophe Büla, University of Lausanne, Switzerland; Alexander Bürkle, University of Konstanz, Germany; Antonio Cherubini, Uniniversity of Perugia, Italy; Gaetano Crepaldi, University of Padua, Italy; Frank de Man, University Rotterdam, Holland; Hanneli Dohner, University of Hamburg, Germany; Deborah Dunn-Walters, Kings College London, UK; Harriet Finne-Soveri, Stakes and Municipality of Helsinki, Finland; Alain Franco, University of Grenoble, France; Tomasz Grodzicki, Jagiellonian University, Cracow, Poland; Pidder Jansen-Dürr, Austrian Academy of Science, Austria; Tomasz Kostka, Medical University, Gdańsk, Poland; Jacek Kuźnicki, International Institute of Molecular and Cell Biology, Warsaw, Poland; Józef Lisowski, Institute of Immunology and Experimental Therapy, Wroclaw, Poland; Bruno Lunenfeld, ISSAM, Israel; Adriana Maggi, University of Milan, Italy; Stefania Maggi, EUGMS-IAGG Working Group, Spain; Jean-Pierre Michel, University of Geneva, Switzerland; Peter Millard, University of London, UK; Jolanta
Perek-Bialas, School of Economics, Warsaw, Poland; Eleni Petridou, University of Athens, Greece; Valdis Pirags, University of Riga, Latvia; Joanna Rymaszewska, Medical University, Wrocław, Poland; Andrzej Kiejna, Medical University, Poland; Dawn Skelton, Prevention of Falls Network Europe, Glasgow, UK; Jarosław Sławek, Medical University, Gdańsk, Poland; Jacek Spławinski, National Medicine Institute, Warsaw, Poland; Merja Suominen, University of Helsinki, Finland; Nektarios Tavernarakis, Institute Biology and Biotechnology, Crete, Greece; Chris Todd, University of Manchester, UK; Eva Topinkova, Medical University, Prague, Czech Republic; Urszula Tworowska-Bardzińska, Medical University, Wroclaw,Poland, Katarzyna Wieczorowska-Tobis, Medical University, Poznań, Poland; Wolfgang Wuttke, Medical University of Goetingen, Germany and Witold Zatoński, National Institute of Oncology, Warsaw, Poland.

and active participation of our honorary guests: Ewa Kopacz, Ministry of Health, Poland; Klaus Theo Schrõder, Federal Ministry of Health, Germany; Reinis Joksts, Latvian Ministry of Health, Marketa Hellerova , Ministry for Health Care, Czech Republic; Jerzy Buzek, Member of European Parliament, Poland; Irena Belohorska, Member of European Parliament, Slovakia; Anita Linell, Swedish National Institute of Public Health, Sweden, Marianne Lidbrink, National Board of Health and Welfare, Sweden; Ann-Kristin Granberg, National Board of Health and Welfare, Sweden; Androulla Agrotou, Ministry of Health, Cyprus; Eleni Isi An- 
gelidou Aglandjia Health Center, Cyprus; Dan Georgescu , European Union of Medical Specialists - Section of Psychiatry, Switzerland; Andras Szilágyi, University of Pecs, Hungary; Patrick Kluczynski, Social Affairs Attaché, French Embassy; Alicja Macke-Nauman, Medical Centre of Postgraduate Education, Warsaw, Poland; Joanna Antonowicz-Juchniewicz, Medical University of Wrocław, Poland; Ewa Bar-Andziak, Medical University of Warsaw, Poland; Janusz Nauman, Medical University of Warsaw, Poland; Jerzy Sowiński, Medical University of Poznań, Poland; Grażyna BednarekTupikowska, Medical University of Wrocław, Poland; Małgorzata Bilińska, Medical University of Wrocław, Poland; Marek Bolanowski, Medical University of Wrocław, Poland; Szymon Dragan, Medical University of Wrocław, Poland; Małgorzata Karbownik-Lewińska, Medical University of Łódź, Poland;, Aleksander Kobylarek, University of the Third Age, Wrocław, Poland; Jerzy Kołodziej, Medical University of Wrocław, Poland; Jan Kornafel, Medical University of Wrocław, Poland, Beata Kos-Kudła, Silesian Medical University in Katowice, Poland; Barbara Krzyżanowska-Świniarska, Medical University of Szczecin, Poland; Ryszard Andrzejak, Medical University Wroclaw, Poland; Andrzej Lewiński, Medical University of Łódź, Poland; Elżbieta Łomna-Bogdanov, Regional Hospital in Opole, Poland;
Zbigniew Machaj, Medical University of Wrocław, Poland.

It was modified based on input by a group of experts convened for the European Summit on Age-Related Disease (Wroclaw, 11-13 September 2008), held under the French Presidency of the European Union.

The report and recommendations have the support of the European Union Geriatric Medicine Society, the International Association of Geriatrics and Gerontology - European Region, the European Association of Geriatric Psychiatry, the International Society for Gerontechnology, and the International Society for the Study of the Aging Male.

\section{This document should be quoted:}

Cruz-Jentoft AJ, Franco A, Sommer P, Baeyens JP, Jankowska E, Maggi A, Ponikowski P, Ryś A, Szczerbińska $K$, Milewicz A and all other participants of the EUROPEAN SUMMIT - AGE-RELATED DISEASES:

European Silver Paper on the Future of Health Promotion and Preventive Actions, Basic Research, and Clinical Aspects of Age-Related Disease. European Summit on Age-Related Disease. Wroclaw, 2008.

Reproduction is authorised, except for commercial purposes, provided that the source is acknowledged. 